\title{
Study on Occurrence of Titanium Element in Anatase Ores of Shazi, Qinglong, Guizhou Province
}

\author{
Min Zhang ${ }^{1, \text { a }}$, Aiguo Nie ${ }^{1, b}$, , Fei Xie ${ }^{2}$ and Zhuru Zhang ${ }^{2}$ \\ ${ }^{1}$ College of Resources and Environmental Engineering, Guizhou Institute of \\ Technology, Guiyang, 550003, China \\ ${ }^{2}$ Guizhou University, Guiyang, 550003, China \\ 551595459@qq.com, bnieaiguo@163.com \\ *corresponding author: Aiguo Nie
}

\begin{abstract}
The tectonic position of anatase deposit in Shazi area, Qinglong, Guizhou Province is located at the transitional area between Yangtze Platform and the western part of South China orogenic belt. Three industrial ore bodies in this deposit are yielded above the limestone Karst unconformity of the Middle Permian Maokou Formation and at the bottom of Emeishan basalt. Genetic type of deposit is hot water -eluvium talus sedimentary which is related to the eruption of Emeishan basalt. Based on the analysis of chemistry, X-ray phase, electron probe and microscopic identification, etc., the data suggest that $\mathrm{TiO} 2$ in anatase ores are mainly present in the form of microgranular inclusions in silicate and quartz; secondly, Ti occurs as isomorphism in limonite; few are as independent minerals existing in the anatase with particle size greater than $0.04 \mathrm{~mm}$. According to the occurrence of Ti, it is determined that the anatase ores are extremely refractory, using conventional processing methods (heavy, magnetic, flotation) are not effective in enrichment anatase, but "roasting- acid leaching-alkaline leaching" beneficiation process works and obtain anatase with $42.32 \%$ TiO2. Extraction method can also enrich the associated element Sc, obtaining $99.99 \%$ scandium oxide products, and the leaching rate of $S c$ is $90 \%$, which can produce iron oxide red and poly aluminum silicate salt (PSA) coagulant by-product. Mineral resources can be effectively developed and utilized without emission, which can obtain good environmental benefits.
\end{abstract}

Keywords: We would like to encourage you to list your keywords in this section.

\section{Introduction}

Titanium (Ti) is a transitional metal element of silver and white color, and in the fourth period and the group IVB of elements periodic table [1]. Its characteristics include light weight, high strength, having metal luster, and resistance to wet chlorine corrosion [2-4]. The chemical character of $\mathrm{Ti}$ is active, so there is no pure titanium in nature, and it is always associated with oxygen [5-6]. In minerals, Ti mainly exists in the forms of $\mathrm{TiO} 2$ and titanate, and often occurs with iron symbiosis. The main minerals of titanium include rutile, anatase, ilmenite, brookite, perovskite, ilmenite, titanite, pseudobrookite, titanomagnetite, and ilmenite, etc. [7]. Our study mainly focuses on the anatase deposit in Shazi area, Qinglong, Guizhou. Anatase one of the 14 strategic reserves of mineral resources heavily dependent on external resources, is the serious shortage of minerals in China [5-6, 8-9]. The theoretical research on newly discovered large anatase deposit at Shaizi, Qinglong just begins, and there are many aspects are still waiting for further work. Here we study the occurrence of anatase in the deposit, which has great significance to enrich the genetic theory of anatase deposit. 
Shazi anatase deposit is located at southeastern Guizhou, the tectonic position of which is at the transitional area between the southwest margin of Yangtze Platform and the western part of South China orogenic belt. It is in the east of Emeishan basalt rocks which are controlled by NS-trend Eastern Yunnan deep seated fault, NW-trend Yadu-Ziyun deep seated fault and WE-trend Nayong-Weng'an deep seated fault [10].

Shazi anatase deposit was a large residual slope type deposit, discovered by Professors Aiguo Nie, Ruzhu Zhang, and the author in 2007 at Qinglong County, Guizhou Province. General survey and detail investigations of this deposit had been worked during 2007 2011. The proved restores of the anatase deposit is 23060900 tons, quantity of TiO2 is 1024800 tons, and the average grade of $\mathrm{TiO} 2$ is $4.39 \%$ [10-12]. Previously, sedimentary metamorphic and hydrothermal modified-type anatase deposits were only discovered at Yangtizi Mountain- Moshi Mountain in Inner Mongolia [8-9]. Shazi anatase deposit is the first one discovered in the weathered residual slope soil of Emeishan basalt in Guizhou, and it is also the first large eluvium talus- type anatase deposit, which ended the history of Guizhou province without Titanium resources and has great practical significance for the reevaluation of the mineral resources in Southwest Guizhou.

Shazi anatase deposit mining area in Qinglong is located at the southwest limb of Bihenying dome-shaped anticline, and the exposed strata, in ascending order, includes Middle Permian Qixia and Maokou Formation; Upper Permian Emeishan Basalt Formation, Longtan Formation and Quaternary. There are three ascertain industrial ore bodies, 'which are oriented in NESW, and they are numbered successively as (1)(2)(3). The ore bodies are yielded above the limestone Karst unconformity of the Middle Permian Maokou Formation and at the bottom of Emeishan basalt [10-11].

\section{Components of Ore}

\subsection{Ore Type}

Ore type is oxidized ore, and generally can be divided into five types: clayey oxide ore, siliceous clayey oxide ore, siliceous tuffaceous clay oxidized ore, siliceous clay oxidized manganese oxide ore of iron and Kaolin siliceous oxide ore. Ores are mainly red and yellow clay and loam bearing anatase, and clay often contains breccias, which are dominated by basaltic pyroclastic rock, clay siliceous rock, iron manganese clay and tuff, etc. Gravel size ranges from $2 \mathrm{~mm}$ to tens of centimeters.

\subsection{Chemical Composition Characteristics of Ore}

From the data of Tab. 1, the contents of $\mathrm{Si}, \mathrm{Al}, \mathrm{Ti}$ and $\mathrm{Fe}$ in Shazi anatase ores are greater than $1 \%$, which is correspond with the result of Tab. 2; the main oxides in ores include $\mathrm{SiO}_{2}, \mathrm{Al}_{2} \mathrm{O}_{3}, \mathrm{Fe}_{2} \mathrm{O}_{3}$ and $\mathrm{TiO}_{2}$, and the content of them is $81.64-88.15 \%$ in total, which is close to the characters of modern laterite weathering crust and red clay type gold deposit in western Guizhou [13], but the content of $\mathrm{TiO} 2$ is higher than gold deposit. Iron in the ores occurs as $\mathrm{Fe} 2 \mathrm{O} 3$, which reflects the strong weathering and completely oxidation of ores. Content of $\mathrm{SiO}_{2}$ is less than 55\%, indicating they are clay ores. Contents of $\mathrm{TiO}_{2}$ and $\mathrm{Fe}_{2} \mathrm{O}_{3}$ are positively correlated, and the correlation coefficient is $91.06 \%$, which suggests the relationship between the anatase and the iron minerals of the original rock is paragenesis. There is a positive correlation between LOSS and contents of $\mathrm{TiO}_{2}$ and $\mathrm{Al}_{2} \mathrm{O}_{3}$, and the correlation coefficients are $86.21 \%$ and $66.36 \%$, respectively, which indicates the relationship between anatase and clay minerals of original rocks is paragenesis. 
Table 1. Spectrum Analysis Results of Shazi Anatase Ores

\begin{tabular}{|c|c|c|c|c|c|c|c|c|}
\hline $\begin{array}{c}\text { Elemen } \\
\mathrm{t}\end{array}$ & $\mathrm{Ba}$ & $\mathrm{Be}$ & As & $\mathrm{Si}$ & $\mathrm{Sb}$ & $\mathrm{Ge}$ & $\mathrm{Mn}$ & $\mathrm{Mg}$ \\
\hline $\begin{array}{c}\text { Content } \\
\%\end{array}$ & 0.02 & $<0.001$ & 0.1 & $>5$ & $<0.01$ & $<0.001$ & $\begin{array}{l}<0 . \\
1\end{array}$ & $<1$ \\
\hline $\begin{array}{l}\text { Elemen } \\
\mathrm{t}\end{array}$ & $\mathrm{Pb}$ & Sn & $\mathrm{W}$ & $\mathrm{Ga}$ & $\mathrm{Cr}$ & $\mathrm{Bi}$ & $\mathrm{Al}$ & Mo \\
\hline $\begin{array}{c}\text { Content } \\
\%\end{array}$ & $\begin{array}{l}<0.0 \\
1\end{array}$ & $<0.01$ & 0.01 & $<0.001$ & $<0.01$ & $<0.001$ & 1 & $<0.001$ \\
\hline$\underset{\mathrm{t}}{\text { Elemen }}$ & V & $\mathrm{Ti}$ & $\mathrm{Li}$ & $\mathrm{Cd}$ & $\mathrm{Ca}$ & $\mathrm{Cu}$ & $\mathrm{Zn}$ & $\mathrm{Ni}$ \\
\hline $\begin{array}{c}\text { Content } \\
\%\end{array}$ & 0.04 & 1 & $<0.01$ & $<0.001$ & $<1$ & 0.1 & 0.02 & 0.01 \\
\hline $\begin{array}{l}\text { Elemen } \\
\mathrm{t}\end{array}$ & Co & $\mathrm{Fe}$ & Y & $\mathrm{Yb}$ & $\mathrm{La}$ & $\mathrm{Nb}$ & $\mathrm{Zr}$ & $\mathrm{Sr}$ \\
\hline $\begin{array}{c}\text { Content } \\
\%\end{array}$ & 0.01 & $>5$ & $<0.01$ & $<0.001$ & $<0.003$ & $<0.001$ & 0.02 & 0.02 \\
\hline $\begin{array}{l}\text { Elemen } \\
\mathrm{t}\end{array}$ & K & $\mathrm{Na}$ & $\mathrm{Ag}$ & $\mathrm{Sc}$ & $\mathrm{P}$ & B & I & I \\
\hline $\begin{array}{c}\text { Content } \\
\%\end{array}$ & $<1$ & $<0.1$ & $<0.0001$ & $<0.001$ & $<0.1$ & $<0.1$ & I & I \\
\hline
\end{tabular}

Table 2. Analysis of Chemical Elements of Shazi Anatase Ore

\begin{tabular}{cccccccc}
\hline Element & $\mathrm{TiO}_{2}$ & $\mathrm{Fe}$ & $\mathrm{Cu}$ & $\mathrm{Co}$ & $\mathrm{Ta}$ & $\mathrm{Nb}$ & $\mathrm{Au}\left(10^{-6}\right)$ \\
\hline $\begin{array}{c}\text { Content } \\
\%\end{array}$ & 4.00 & 14.92 & 0.014 & 0.008 & $<0.005$ & 0.005 & 0.2 \\
$\begin{array}{c}\text { Element } \\
\begin{array}{c}\text { Content } \\
\%\end{array}\end{array}$ & $\mathrm{Ni}$ & $\mathrm{CaO}$ & $\mathrm{MgO}$ & $\mathrm{Al}_{2} \mathrm{O}_{3}$ & $\mathrm{SiO}_{2}$ & $\mathrm{Na}_{2} \mathrm{O}$ & $\mathrm{K}_{2} \mathrm{O}$ \\
\hline
\end{tabular}

\subsection{Composition Characteristics of Ore Mineral}

The results of the identification and $\mathrm{X}$ ray analysis show that main minerals in the ores include anatase, limonite, a small amount of magnetite, ilmenite, pyrite and arsenopyrite. Gangue minerals are dominated by kaolinite, sericite, chlorite and quartz, and also contain plagioclase, few zircons, tourmaline and epidote, etc. Ore composition is complexity, and minerals retained from the original rocks include limonite basalt, limonite siliceous rocks, clay siliceous rocks, clay basaltic pyroclastic rock interbedded with clay, etc.

Based on the analysis of X-ray phase, electron probe, artificial heavy concentrate and microscopic identification, etc., the data suggest that there are 14 kinds of minerals assigned to oxide, silicate and sulfide. Oxide accounts for about $38.7 \%$, among which anatase accounts for $4.6 \%$, quartz takes up $9 \%$, and ilmenite is rare. Silicate accounts for about $61 \%$, including $48 \%$ of kaolinite, $9 \%$ of sericite (muscovite), $3 \%$ of chlorite and less than $1 \%$ of plagioclase, other silicate minerals are only occasionally seen in the heavy fraction; sulfide occurs occasionally in ores. 


\section{Titanium Independent Minerals and Carrier Minerals}

\subsection{Identification of Titanium Independent Minerals and Carrier Minerals}

According to the analysis of electron probe, polarizing microscope and X-ray phase, the result suggests that the titanium independent minerals in Shazi anatase ores includes anatase and ilmenite, among which ilmenite occurs occasionally in ores. The carries minerals of titanium include limonite, quartz and silicate minerals (such as kaolinite, sericite (muscovite), chlorite and plagioclase, etc.).

Under polarizing microscope, anatase is mainly distributed in the seriously altered basalt in form of xenomorphic granular, dendritic and muddy and usually has intergrowth relationship with quartz, feldspar and kaolinite, etc. Some of anatase were wrapped in gangue minerals, or distributed in the cracks of quartz and feldspar, and sometimes associated with iron, which may result from the dark-colored mineral decomposition in the process of rock alteration, minerals grains are very fine (Fig. 1 a-e). In the artificial heavy concentrates, granular anatase are rare under stereomicroscope, which only accounts for $0.15 \%$; (ore samples for artificial heavy concentrates are greater than $0.05 \mathrm{~mm}$ ), anatases under artificial heavy concentrates are green and yellowish-brown, adamantine luster, oily luster of fracture, quartet double cone-shaped and xenomorphic granular (Fig.1f). However, anatases with grains smaller than $47.2 \mu \mathrm{m}$ account for $96.35 \%$ under polarizing microscope, while the grains smaller than $23.6 \mu \mathrm{m}$ account for $75.37 \%$, which reflects that the insetting grain size of anatase is small.

Through polarizing microscope investigation, the majority of limonite is disseminated in form of mud in clay minerals and the granularity is smaller than $0.004 \mathrm{~mm}$. A few occur as xenomorphic granular, mud and colloidal, xenomorphic granular limonite is distributed along the cracks of gangue and argillaceous. Colloidal limonite usually occurs among other minerals as cement, and mixed with clay minerals, less of them are present as granular particles, size ranges from $0.05 \mathrm{~mm}$ to $0.3 \mathrm{~mm}$ (Fig. $1 \mathrm{~g}, \mathrm{~h}$ ).
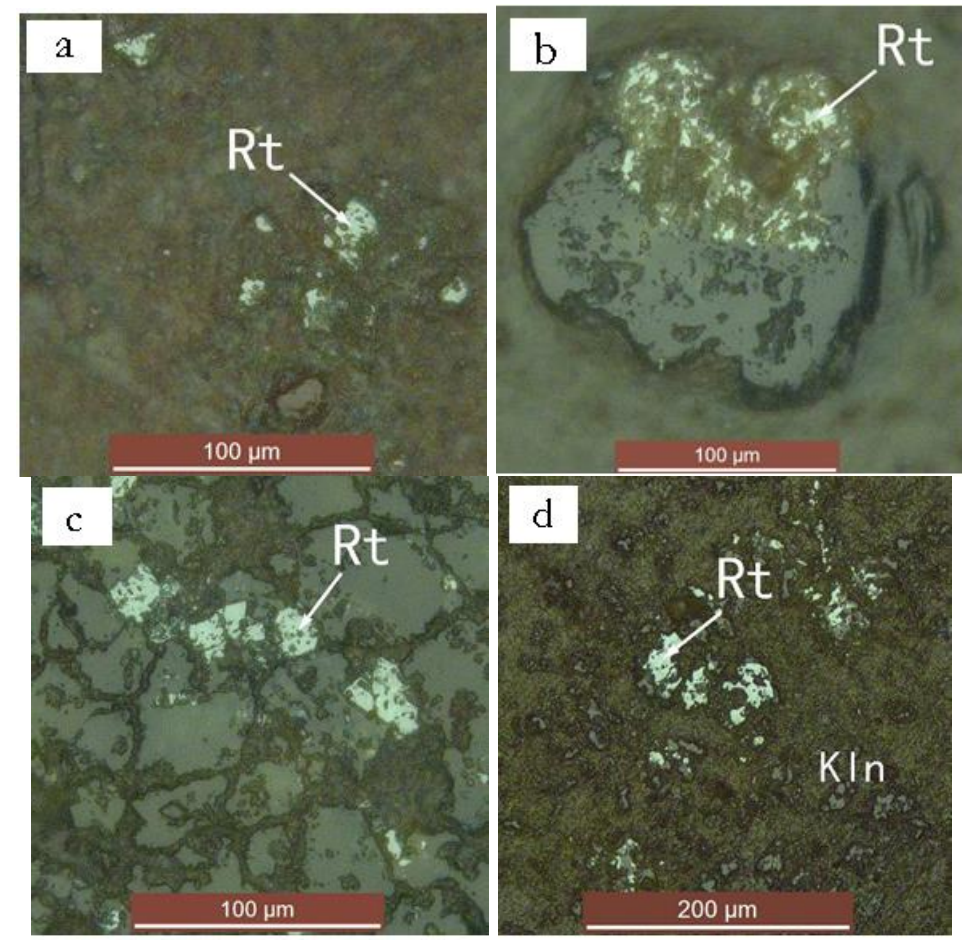

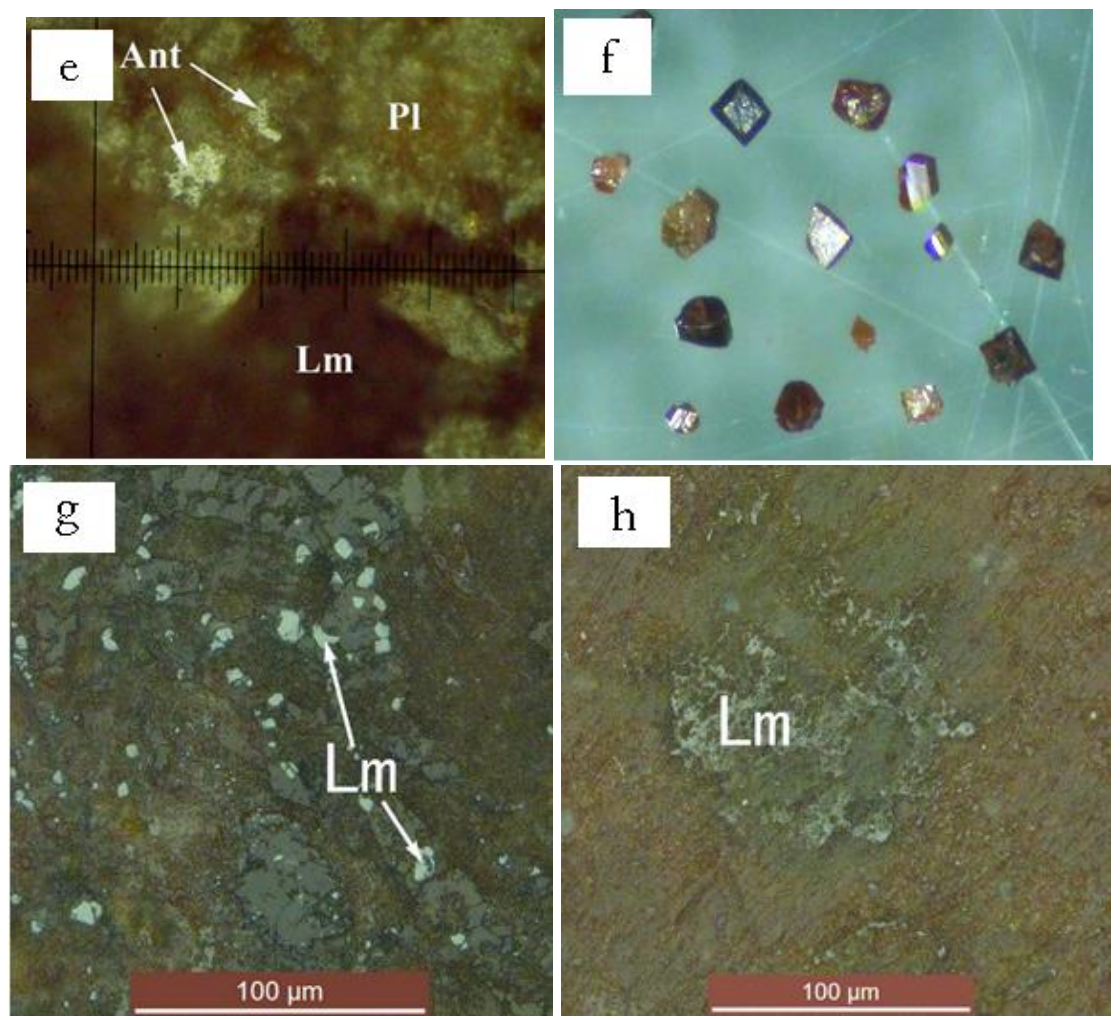

Figure 1. Micrographs

a, anatase associated with gangue, reflection single polarization; $b$, anatase associated with gangue, reflection single polarization; c, anatase distributed in the cracks of gangue, reflection single polarization; d, anatase associated with kaolinite, reflection single polarization; e, anatase wrapped in the plagioclase, reflection single polarization, every single lattice of scale $=0.006 \mathrm{~mm}$; $\mathrm{f}$, anatase in artificial heavy concentrate, observed under stereomicroscope; g, xenomorphic granular limonite, reflection single polarization; $\mathrm{h}$, limonite disseminated other minerals, reflection single polarization. Rt, Ant: anatase; Kln: kaolinite; Pl: plagioclase; Lm: limonite.

\subsection{Electronic Probe}

According to the analysis of electron probe, polarizing microscope and polarizing microscope, minerals bearing $\mathrm{Ti}$ in ores can be divided into two types: independent minerals of titanium and the carrier of titanium minerals. According to the content of titanium in different minerals, the results of the electron probe analysis of the major titanium bearing minerals are as follows:

Anatase: molecular formula is $\mathrm{TiO}_{2}$, the content is about $4.6 \%$, which is the main recycle target in ores. Based on electron probe analysis, anatase contains $51.37 \% \mathrm{Ti}$, $47.72 \% \mathrm{O}$, and $0.91 \% \mathrm{Si}$ (Fig. 2). The content of $\mathrm{TiO} 2$ in anatase minerals is uneven and ranges from $87 \%$ to $95 \%$, which may be attributed by alteration. Besides, there are Sc and small amount of other elements in anatase, which is the main carrier of Sc, but the content of $\mathrm{Sc} 2 \mathrm{O} 3$ is uneven, ranging from $0.1 \%$ to $0.03 \%$. Backscattered electron images of anatase are shown in Fig.3, they are white and distributed in scattered shape.

Ilmenite: molecular formula is $\mathrm{FeTiO} 3$, it is rare in ores, and usually associated with kaolinite, granularity ranges from $0.01 \mathrm{~mm}$ to $0.05 \mathrm{~mm}$. Based on electron probe analysis, ilmenite contains $34.50 \% \mathrm{Ti}, 15.14 \% \mathrm{Fe}, 46.54 \% \mathrm{O}, 0.70 \% \mathrm{~V}$ and a small amount of $\mathrm{Al}$, $\mathrm{Si}$ and As. Under stereomicroscope, ilmenite is black, submetallic luster, clintheriform and xenomorphic granular, occasionally occur in artificial heavy concentrate. Granularity ranges from $0.01-0.05 \mathrm{~mm}$. The content of $\mathrm{TiO}_{2}$ in ilmenite is about $57 \%$. 
Limonite: molecular formula is $\mathrm{FeOOH}$, he content is about $26 \%$. Components of limonite include $\mathrm{Fe}(47.73 \%, 54.39 \%)$, O $(42.75 \%, 39.22 \%)$, Ti $(6.40 \%, 5.85 \%)$ and a little $\mathrm{Si}, \mathrm{Al}$ and $\mathrm{Ca}$. Average content of $\mathrm{FeO}$ in limonite is $70-80 \%$, the iron content is not uniform, which may result from the uncertain content of moisture and mix of other minerals. Content of $\mathrm{TiO}_{2}$ is 3.6-19\%, which may come from the alteration of limonite. There are also some other components in limonite. The data indicate that $\mathrm{Fe}$ and $\mathrm{Ti}$ are negatively correlated.
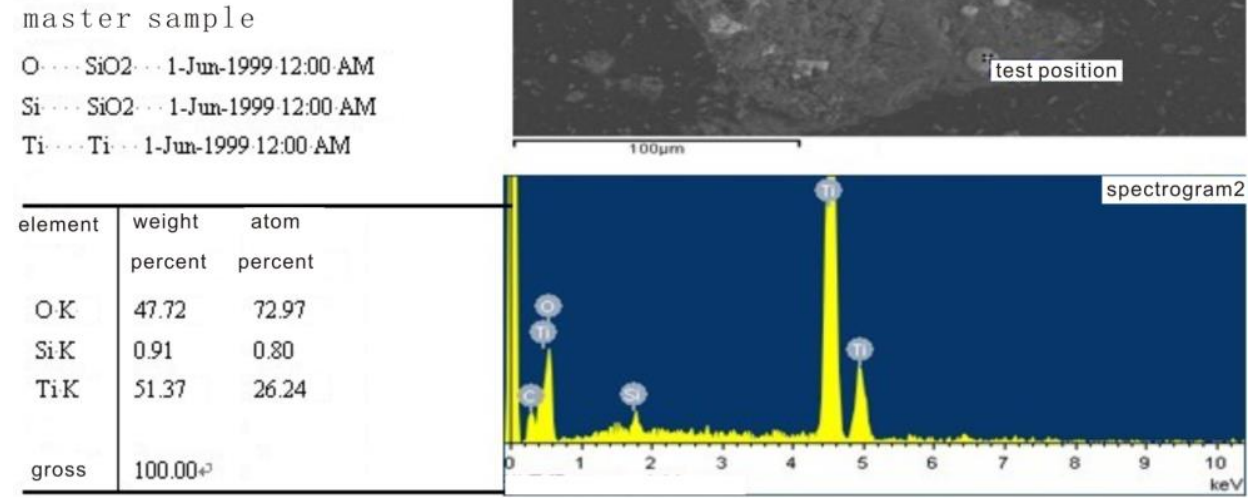

Figure 2. Electron Microprobe Analysis and Atlas of Anatase

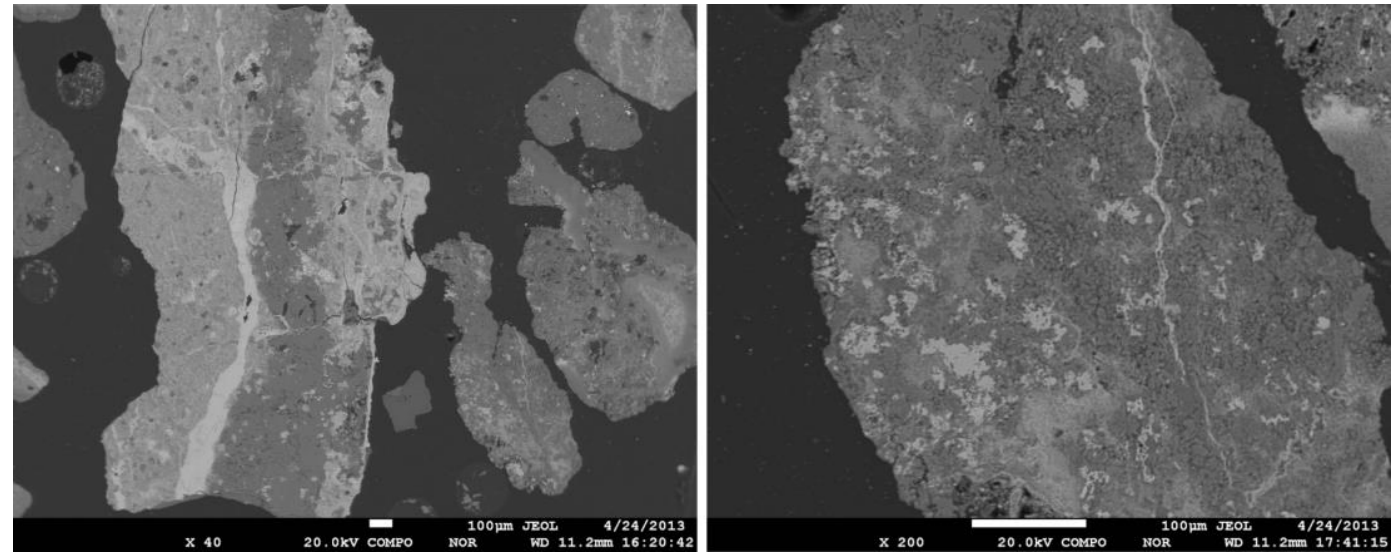

Figure 3. Backscattered Electron Image of Anatase

Kaolinite: molecular formula is $\mathrm{Al}_{4}\left[\mathrm{Si}_{4} \mathrm{O}_{10}\right](\mathrm{OH})_{8}$, the content in ore is about $48 \%$. It is the main gangue mineral, usually occurring as microscopic scales, mud and cryptocrystalline, and widely distributed in ores. Most of the kaolinites are disseminated to brown by iron, and the granularity is generally less than $0.004 \mathrm{~mm}$ (Fig. 1d). Based on the analysis of electron probe, kaolinite contains $0.275 \%-0.426 \%$ of $\mathrm{TiO} 2$ and $0.01 \%$ of $\mathrm{Sc}_{2} \mathrm{O}_{3}$, which indicates that both $\mathrm{Ti}$ and $\mathrm{Sc}$ are common in this mineral, but the content of $\mathrm{Sc}$ is less than Ti.

\section{Occurrence of $\mathrm{Ti}$}

The data of chemical analysis of ore samples collected from the studied area reveals that $\mathrm{Ti}$ mainly exists in the form of $\mathrm{TiO}_{2}$, and the average content of $\mathrm{TiO}_{2}$ is $4.0 \%$. 
According to the analysis of microscopic observation, X-ray phase, electron probe and single mineral chemistry, anatase $\left(\mathrm{TiO}_{2}\right)$ with grains smaller than $0.04 \mathrm{~mm}$ usually occurs in the form of micro-fine inclusions in silicate and quartz. Multipoint electron probe of limonite shows that limonite may be the product of ilmenite alteration. The contents of $\mathrm{Fe}$ and $\mathrm{Ti}$ are negatively correlated, which proves part of $\mathrm{Ti}$ exists in the form of isomorphism in limonite. A small part of Ti exists in the form of independent mineral in anatase with granularity greater than $0.04 \mathrm{~mm}$.

$\mathrm{TiO}_{2}$ is mainly in the form of micro-fine inclusions in silicate and quartz, and accounts for $77.38 \%$. This part of the $\mathrm{TiO}_{2}$ exists in the form of mud and fine anatase inclusions in gangue minerals, and is difficult to smelt. Even the particle size of grinded ore samples is smaller than $0.04 \mathrm{~mm}$ for the isolation of single minerals, but there are still anatases in the gangue minerals. $\mathrm{Ti}$ is secondly in the form of isomorphism in limonite, which accounts for $18.97 \%$. However, $\mathrm{Ti}$ in the form of independent mineral $\left(\mathrm{TiO}_{2}\right)$ in the anatase with granularity greater than $0.04 \mathrm{~mm}$ only takes up $3.65 \%$.

According to the above analysis, there are three kinds of occurrence of Ti in the ores: in the fine-grained independent anatase which is paragenesis or embedded with gangue minerals; in the form of anatase mineral wrapped in the silicate minerals and quartz; in the form of isomorphism in limonite. The occurrence of Ti suggests that the resource in the ores is extremely difficult to separate.

\section{Discussion of Ore Beneficiability}

According to the occurrence of $\mathrm{Ti}$, it is determined that anatase ores are extremely difficult to process. The conventional mineral processing method (gravity, magnetic and flotation) cannot effectively enrich the anatase [12, 14]. However, the ore dressing process of "roasting-acid leaching -alkali leaching" can be applied to raw ores, and the selected ore grade of $\mathrm{TiO}_{2}$ is $4.00 \%$, which can obtain anatase with $42.32 \% \mathrm{TiO}_{2}$, recycle rate is $83.16 \%$. Anatase with $42.32 \% \mathrm{TiO}_{2}$ can be sold as concentrates. Other elements dissolving out, e.g. Sc, $\mathrm{Fe}, \mathrm{Al}$ and $\mathrm{Si}$ can be recycled. It can be received $99.9 \%$ of scandia product by extraction, and the leaching rate of $\mathrm{Sc}$ is $90 \%$. Fe, $\mathrm{Al}$ and $\mathrm{Si}$ can be used to produce iron oxide red and by-product of polyalumicium silicate (PAS) coagulant [12]. According to the mineral processing test in Kunming University of Science and Technology, "roasting-acid leaching -alkali leaching" method works effectively for the extremely refractory ore, and obtains anatase with $42.32 \% \mathrm{TiO} 2,99.9 \%$ of scandia product and iron oxide red and by-product of polyalumicium silicate (PAS) coagulant. Mineral resources without emission can be effectively utilized, and can get very good environmental benefits.

Application of anatase is extensive [13]. The high grade titanium dioxide (TiO2) is an important raw material for the production of coatings, plastics, ink, paper, chemical fiber, cosmetic, medicine, food and other industries[13,15]. Anatase with good photocatalytic properties [16], is better than rutile in the field of nano photocatalyst and is also applied to air pollution govern, degradation of organic matter in wastewater and car pigment, etc. [13]. The success of the experiment of the mineral processing of Shazi anatase deposit indicates that this ore can produce huge economic value to accelerate the construction of resource type city in southwestern Guizhou, to serve the economic construction of Guizhou Province, which has great social benefit and economic benefit.

\section{Conclusions}

From the data of above analysis, the following conclusions are drawn: (1) ore reserves of Shazi anatase deposit in Qinglong is 23060900t, resources quantity of $\mathrm{TiO}_{2}$ is $1024800 t$; average grade of $\mathrm{TiO}_{2}$ is $4.39 \%$. (2) The titanium element in the anatase ore is mainly in the form of anatase inclusions with granularity less than $0.04 \mathrm{~mm}$ in silicate and quartz minerals; secondly, it is in the form of isomorphism in limonite and a minority of 
Ti exists in the form of independent mineral in the anatase with granularity greater than $0.04 \mathrm{~mm}$. (3) Ores are extremely refractory, as for the micro-fine anatase inclusions in silicate and quartz, even the particle size of grinded ore samples is smaller than $0.04 \mathrm{~mm}$ for the isolation of single minerals, but there are still anatases in the gangue minerals. This part of anatase accounts for $77.38 \%$. (4) According to the refractory characteristics, the ore dressing process of "roasting-acid leaching -alkali leaching" can obtain anatase containing $42.32 \% \mathrm{TiO}_{2}$ with recycle rate $83.16 \%$. (5) The existing properties and recycling value of $\mathrm{Fe}, \mathrm{Sc}, \mathrm{Al}, \mathrm{Si}$ and other beneficial elements in the anatase ore are still waiting for further work.

\section{Acknowledgment}

This work was supported by the national natural science foundation of China of firstly discovered anatase deposits in Guizhou--analysis on metallogenic mechanism of large scaled anatase deposit of shazi area in Qinlong county (No.41262005), and the schoollevel project of analysis on genetic mechanism of typical deposit of Emei mantle plume activity in western Guizhou, China (No.XJGC20140702).

\section{References}

[1] P. Shen, Y. Chen and Y. Luo, "Inorganic chemistry, Science press, (1998), pp. 352-413.

[2] Q. Fu Qiuya and C. Wan, "Production technology of the titanium mobile shell", Titanium industry progress, vol. 24, no. 5, (2007), pp. 33-35.

[3] X. Wang, F. Lu and J. Hong, "The outline of titanium industry in China", Titanium industry progress, vol. 25, no. 1, (2008), pp. 1-8.

[4] G. Tian, Q. Hong and L. Zhang, "Titanium alloys applied for large civil airliner abroad", Titanium industry progress, vol. 25 , no. 2, (2008), pp. 19-22.

[5] C. Duan, "An analysis and evaluation for the situation of titanium resources", Sichuan nonferrous metals, vol. 21, no. 1, (2000), pp. 31-36.

[6] X. Wu and J. Zhang, "Geographical distribution and characteristics of titanium resources in China", Titanium industry progress, vol. 23, no. 6, (2006), pp. 8-12.

[7] K. Chen, "Research on comprehensive utilization of low-grade ilmenite", Master degree, Zhongnan University, China, (2013), pp. 30-42.

[8] Y. Zhao, D. Li and W. Cheng, "Yangtizishan metamorphosed sedimentary titanium deposit: Discovery of new genetic type of titanium deposit", Mineral deposits, vol. 25, no. 2, (2006), pp. 113-122.

[9] Y. Zhao, D. Li and L. Wu, "Geology and geochemistry of Yangtizishan-Moshishan anatase ore deposit in Zhenglanqi County, Inner Mongolia: Asummary of exploration and investigation work”, Mineral deposits, vol. 27, no. 4, (2008), pp. 425-447.

[10] M. Zhang, A. Nie and F. Xie, "Study on the element geochemical charactersitics of the Shazi large-sized anatase ore deposit in Qinglong, Guizhou province. Chin", Journal of Geochem, vol. 33, (2014), pp. 316-323.

[11] A. Nie, Z. Zhang and G. Kang, "Geological characteristics of firstyly discovered eluvial type of anatase deposits in Guizhou", Journal of Guizhou University, vol. 28, no. 3, (2011), pp. 41-44.

[12] M. Zhang, A. Nie and F. Xie, "Discovery and study on exploitation and utilization of Shazi Large-scale anatase deposit in Qinglong County of Guizhou Province", Mining Research and Development, vol. 35, no. 1, (2015), pp. 6-9.

[13] Z. Gao and H. Li, "Mineralization and exploration of main sorts of gold ore in Guizhou and Yunan, China", Geology press, (2002), pp. 102-112.

[14] J. Zhang, X. Xu and J. Jiang Yan, "Study on process mineralogy of a refractory anatase ore in Guizhou and Discussion on its separability", Yunan Metallurgy, vol. 41, no. 3, (2012), pp. 10-16.

[15] J. Cao, "Titanium sources and their tapping and utilization", Geology of chemical minerals, vol. 18, no. 2, (1996), pp. 127-134.

[16] F. Ran, W. Cao, Y. Li, and X. Zhang, "Preparation of anatase nano-TiO2 powders by hydrothermal synthesis", vol. 21, no. 3, (2006), pp. 33-35. 